\title{
Divided Once More: Social Memory and the Canadian Conscription Crisis of the First World War
}

Andrew Theobald, Queen's University

The conscription crisis is central to both the Canadian experience of the Great War and to collective conceptions of the nation(s) itself. As such, there have been many explorations on the subject. Until very recently, these studies concentrated on military accomplishments and on deciphering the earliest Canadian representation on the world stage. However, Jonathan Vance's ground-breaking 1997 study Death So Noble prompted a wholesale reassessment of the social memory of the conflict. This reassessment shifted emphasis to questions of how future generations have remembered the First World War and to why they have chosen to do so. While there are no structural commemorations to the conscription crisis, it remains tangible through textbook explanations, popular fiction, and in documentary films largely created in Ontario and Québec. The work produced in Ontario reflects the Canadian nationalist viewpoint, stressing the benefits of unity through an emphasis on shared past accomplishments. The work produced in Québec concentrates on opposition to conscription as a means of emphasizing the long history of Québec distinctiveness.

The basis for these contested positions is this. When the First World War began in August 1914, Canada virtually unanimously declared its support for Great Britain and its allies against the German-led central powers. The national patriotic response resulted in the timely raising of a Canadian Expeditionary Force (CEF) for service on the Western Front. Although some, 
especially Québec's French-Canadians (who referred to themselves as Canadiens at the time), expressed concerns that conscription might be imposed, the measure remained completely unnecessary in those heady days.

Throughout 1915-16, voluntary recruiting met the growing need for soldiers. Indeed, the first calls for selective conscription 2) were not heard until the mid-1916 allied Somme offensive, which cost 24,000 Canadian and 600,000 British Empire casualties. By that time, Great Britain had followed the lead of Austria-Hungary, France, Germany, Italy, Russia, and all of the other major belligerents in introducing national service.

By 1917, however, the allied war situation had become desperate. With the prolonged fighting, the high casualties, and the fact that virtually all of those who wished to enlist had already done so, recruiting efforts stalled. Québec's French-speaking majority suffered the brunt of the blame for this phenomenon. The veracity of this claim is difficult to prove, since no questions were asked about "race," ethnic origin, or mother tongue on CEF attestation papers. Whatever the case, following Conservative Prime Minister Robert Borden's visits to Britain and France early in the year, Parliament enacted conscription. Supporters fought a pitched political and propaganda campaign to win passage of the Military Service Act, with most politicians and soldiers backing the formation of Borden's Union government in late 1917. The Union victory in the December 1917 election demonstrated the Canadian public's support for Borden's principal platform. By the time the armistice was reached on 11 November 1918, 25,000 conscripts had reinforced the 150,000 Canadian troops in Europe. ${ }^{1}$

\footnotetext{
${ }^{1}$ J.L. Granatstein and J.M. Hitsman, Broken Promises: A History of Conscription in Canada (Toronto: Oxford University Press, 1977), 97-8.

Past Imperfect 12 [2006] | (C) |ISSN 1192-1315
} 
Nevertheless, conscription was deeply resented by many Canadians, in particular, Canadiens, farmers, the labour movement, and ethnic minorities throughout the country. Québec certainly led the way, but opposition was not confined to that province. As soon as the Military Service Act and its attendant legislation, the Military Voters Act and the War-Time Elections Act, were introduced, farmers, fishers, and labourers requested exemption in front of specially-established local tribunals. A majority of these requests for exemption were granted. Conscription opponents sought to avoid forced enlistment on the grounds that their occupations were essential to the war effort that they lacked the full benefits of citizenship, or that wealth should be conscripted along with men.

In spite of the variety of opinions inherent in these examples, works dealing with conscription commonly assert that opposition to the measure is best explained by reliance upon Lord Durham's pronouncement of "two races warring in the bosom of a single state." The propensity of Canadian educators and historians to concentrate the study of the conscription crisis solely on Ontario and Québec has cemented this belief.

of course, there was widespread opposition to conscription in Québec and widespread support in Ontario, but why have these events been remembered in this fashion? For one, the predominant modern Québec nationalist view states that opposition to the measure was justified, since conscription targeted a minority within Canada, but a majority within Québec, rightfully more concerned with events at home. Proponents of this position are supporters of Québec sovereignty, despite that Canada-first 1914-18 position. On the other hand, Canadian nationalist social memory ignores the conscription issue, focusing instead on the CEF's 
volunteer citizen-soldiers and the terrible slaughter that also helped to forge a nation. Canadian nationalists are thus those that today stress the unity of the Canadian confederation and focus on the benefits that arose from participation in the war.

Significantly, these social memories are at odds with one another. The feelings of contemporaries, of soldiers who fought 4) together in the trenches, or even of those who first bequeathed the war's legacy in the 1920s and 1930s do not concern either of these camps. Instead, the different perceptions of what should be stressed and what should be forgotten about the crisis, and how this impacts the present, delineate these nationalist social memories. ${ }^{2}$ A survey of textbooks and direct educational material, including novels often assigned in public schools, tenders a more complete view of these differences.

\section{Educating the Nations}

There are an abundance of textbooks that discuss the Canadian role in the Great War. A number of these works, including a 1921 survey by distinguished historian George M. Wrong, make no mention of the conscription crisis and concentrate on the righteousness of the allied cause. The Children's Story of the War series and the 1933 The Story of Our People emphasize the undying glories of British arms, while the Ontario school-authorized A History of the Canadian People espouses loyalty to Britain. ${ }^{3}$ To avoid detracting from the

\footnotetext{
${ }^{2}$ Jonathan Vance, Death So Noble: Memory, Meaning and the First World War (Vancouver: UBC Press, 1997), 3.

${ }^{3}$ George M. Wrong, Ontario Public School History of Canada (Toronto: The Ryerson Press, 1921), 344-54; Sir Edward Parrott, The Children's Story of the War (Toronto: Thomas Nelson \& Sons Limited, 1920s Serial); Gilbert Paterson, The Story of Our People (Toronto: The Ryerson Press, 1933), 418-21; William Stewart Wallace, A 
sacrifices so recently made by so many families, conscription and other contentious topics went unmentioned in these early descriptions.

After the Second World War, and a second conscription crisis, textbooks confronted the issue by stressing positive lessons of cooperation and tolerance. Building the Canadian Nation considered the crisis as a parable:

The most tragic effect of the conscription issue was division and misunderstanding between French and English, some of which could certainly have been avoided. To their great credit, Borden and [Liberal opposition leader Wilfrid] Laurier refused to be swept off their feet by prejudice and passion even when their differences of opinion were irreconcilable. Had their fine example in public debate been followed by everyone, the unhappiest effects of the conscription issue would have been avoided. ${ }^{4}$

Similarly, A Short History of Canada honestly acknowledged the problem, stating that "Such a division on racial lines was a blow at national unity that, even when the bitterness over conscription largely subsided, left scars." Canada Your Country echoed the views of Building the Canadian Nation by emphasizing the wisdom imparted while balancing the blame. In the section entitled "English and French Canadians Clash over Conscription," the work calls for mutual dialogue, stating: "we realize that this whole sorry episode

History of the Canadian People (Toronto: The Copp Clark Company Limited, 1930), 322.

${ }^{4}$ George W. Brown, Building the Canadian Nation (Toronto: J.M. Dent \& Sons Limited, 1942), 411.

${ }^{5}$ G. de T. Glazebrook, A Short History of Canada (Oxford: Clarendon Press, 1950), 205.

Past Imperfect 
had come about because neither the French nor the English had tried hard enough to see the viewpoint of the other."

This claim of tunnel vision fostered by Canadian nationalists in the 1950s and 1960s resonated throughout later decades as well. The 1978 high school text The Canadiana Scrapbook: Canadians at War 1914-1918 best exemplified the message of 6) uncertainty while still stressing the ability to overcome disagreement. The accompanying Teacher's Guide summarized the intended message: "The material indicates why conscription was felt to be necessary and examines the steps taken by the government to win the election." The Guide also posed a provocative counterfactual assignment: "Debate the following: Resolved that the effort to establish compulsory military service should never have been initiated considering that the issue split the country and resulted in only a handful of men reaching France, and almost none getting to the front lines."

With a style that closely resembles textbooks, official productions of the Department of Veterans Affairs use short educational videos to demonstrate how military sacrifices supported Canada's emergence as an independent nation. For example, in the film Canada and the Great War 1914-1918: A Nation Born, a young woman narrates a chronology of wartime achievements. Conscription is briefly described, with the narrator stating, "much strife was created between English and French Canadians, many of whom felt no attachment to the empire and the

${ }^{6}$ J.W. Chafe, Canada Your Country (Toronto: The Ryerson Press, 1950), 347. See also A.B. Hodgetts, Decisive Decades (Toronto: Thomas Nelson \& Sons Limited, 1960), 220. ${ }^{7}$ Donald M. Santor, ed., Canadiana Scrapbook: Canadians at War 1914-1918 (Scarborough: Prentice-Hall of Canada, Ltd., 1978), 42-3 and Teacher's Guide, 68, 72. 
war." Similarly, the film Innocence Lost...A Nation Found: Canada Remembers the Great War 1914-1918, relates the tale of twelve students, one from each province and territory, on a 1997 visit to former Western Front battlefields. Predictably, the idealized conception results in a film that stresses national unity and makes no reference to the crisis. ${ }^{9}$

On the other hand, French language educational material has catalogued Québec-based opposition to the Military Service Act. For example, the one page on the conscription crisis in Québec \& Canada, Histoire du Canada is definitive. First, the reader is informed that Borden decided on conscription following his attendance at the 1917 Imperial Conference. ${ }^{10}$ Although chronologically correct, this statement does not provide the context, such as Borden's corresponding visits to troops in France, necessary to explain the government's momentous decision, thus implying that the Prime Minister merely followed British orders. Comparison with an excerpt accompanied by a photo of Borden speaking with Canadian troops at a military hospital from Our Canada starkly illuminates the difference in emphasis: "Early in 1917, Sir Robert Borden returned from a visit to England and to the Western Front in France, convinced that conscription was the only method by which reinforcements for the Canadian army could be maintained in the face of mounting casualties." 11

Moreover, the Histoire $d u$ Canada coverage of the most violent example of domestic conscription-related protest, the

\footnotetext{
${ }^{8}$ Canada and the Great War 1914-1918: A Nation Born, 19:30 minutes, Veterans Affairs Canada, 1998, videocassette.

${ }^{9}$ Innocence Lost...A Nation Found: Canada Remembers the Great War 1914-1918, 20 minutes, Veterans Affairs Canada, 1998, videocassette.

${ }^{10}$ Albert Tessier, Québec \& Canada, Histoire du Canada Tome II (1763-1958) (Québec: Éditions du Pélican, 1958), 253.

${ }^{11}$ Arthur G. Dorland, Our Canada (Toronto: The Copp Clark Co. Limited, 1949), 390. 
29 March to 2 April 1918 Québec City riots, aptly summarizes Québec nationalist social memory: "Un régiment de Toronto fut envoyé à Québec pour maintenir l'ordre. L'inévitable se produisit: une émeute éclata. La troupe fit claquer les mitrailleuses, tuant quatre civils et infligeant des blessures à plusieurs autres." ${ }^{12}$ Since no additional explanation for this "inevitable" action is provided, 8| the reader is drawn to the resistance in Québec and the violent measures which Ontario soldiers used to quell civilian dissent.

Recent publications reveal that this version of events has gained wide acceptance. Indeed, since the early 1990s, English language textbooks have contained often sympathetic examinations of Québec's treatment within Confederation. Regardless of this important shift, one constant remains: national history textbooks are overwhelmingly published in Ontario and Québec. Any reference to the conscription crisis in British Columbia, the Prairies, the Maritimes, among French-Canadians outside of Québec, or any non-French or British group is confined to regional or case-specific narratives.

Thus, the conscription crisis remains overly simplified. Recent studies also often provide little information about wider war-time events, insinuating that the decision to enact conscription was taken in a vacuum. The prime example of this trend comes from History of the Canadian Peoples. This popular text covers the conscription crisis in a single paragraph, a paragraph overshadowed by prominent sections on the segregated African-Canadian No. 2 Construction Battalion and contemporary maltreatment of Native peoples. The work's coverage of the war is punctuated by this description:

${ }^{12}$ Tessier, Québec \& Canada, 253.

Past Imperfect 12 [2006]| (C) |ISSN 1192-1315 
The shortage of soldiers for the war effort was compounded by the exclusionary policies practiced by the Canadian military. Despite the eagerness of some Canadian women to serve overseas, they were unwelcome on the front lines. The only official role for women in the armed services was as nurses...When Indian, Japanese or African-Canadian men offered their services they, too, were often turned away. ${ }^{13}$

This description widens the scope of inquiries into the Canadian role in the war, but the conscription crisis itself has been overshadowed by the many other inequalities in the nation's past and present society.

\section{Fiction and Conscription}

Nevertheless, textbooks and documentary films are not the only sources of information about the crisis. While English language literature has not dealt extensively with the issue, Hugh MacLennan's 1945 Two Solitudes remains the significant exception to this generalization. Two Solitudes created a quintessential description of Canadian duality, rather than the unity MacLennan intended, and coined a phrase which has entered the vernacular. Significantly, despite the fact that MacLennan lived and worked in Montréal for most of his life, eighteen years passed before the first French language edition of the work, published in Paris, appeared. ${ }^{14}$

\footnotetext{
${ }^{13}$ Alvin Finkel and Margaret Conrad, History of the Canadian Peoples, Vol. II: 1867 to the Present. Second Edition (Toronto: Copp Clark Ltd., 1998), 212-13. Note also the plural "peoples," as opposed to the singular titles A History of the Canadian People (1930), The Story of Our People (1933), Our Canada (1949), and Canada Your Country (1950).

14 "Hugh MacLennan Online Project,"

<http://digital.library.mcgill.ca/maclennan/ts.htm>. Two Solitudes was published

Past Imperfect 12 [2006] | (C) | ISSN 1192-1315
} 
Two Solitudes takes place in Montréal and the fictional rural Québec community of Sainte-Justine between 1917 and 1939. The work's conscription crisis centres on Marius Tallard, idealistic young son of Member of Parliament Athanase Tallard and his Irish-Canadian wife Kathleen. In his thinking on conscription, Marius concurs with the parish priest, who states early on that "this year the English 10l provinces had imposed conscription on the whole country, trying to force their conquest of Quebec a second time." 15

More than any other fictional account, Two Solitudes explores various perceptions of the conscription debate. Musings on anti-war sentiment are contrasted through the plight of Janet Methuen, a wealthy Montréal anglophone whose husband Harvey is killed while serving overseas. Janet later provides information leading to the arrest of Marius, who had become a deserter, because of her bitterness towards those unwilling to serve; explaining her actions to her father, she declares: "Why should these people be allowed to get out of it? Harvey didn't."16

Other English-Canadian literature set during the First World War foregoes in-depth examinations of the crisis. This is because the remembrance of sacrificed innocents predominates. Alden Nowlan's poem "1914-1918” neatly summarizes this:

Thinking again of all those young men who were given the same first name,

Canada, once they had reached the place which we in our innocence then called Overseas, doubtless with the same intonation as Frankish peasants had used eight centuries earlier

in Czech, Dutch, Norwegian, Spanish, Swedish, and in seven English editions before the appearance of the first French edition.

${ }^{15}$ Hugh MacLennan, Two Solitudes (New York: Duell, Sloan and Pearce, 1945), 7.

${ }^{16}$ Ibid., 164. 
in speaking of the sons who had followed their steely Lords to Outre Mar. ${ }^{17}$

English language works favour these themes, characterized by descriptions of the dehumanizing terrors of the Western Front. A prime example of this motif is Robertson Davies' 1970 novel Fifth Business. The protagonist, Corky Ramsay, loses a leg at Passchendaele. As he informs the reader in a speech, "Commanders and historians are the people to discuss wars; I was in the infantry, and most of the time I did not know where I was or what I was doing except that I was obeying orders and trying not to get killed in any of the variety of horrible ways open to me." ${ }^{18}$ Timothy Findley's The Wars similarly emphasizes horrific descriptions, as in this passage on the Battle of St. Eloi:

When they made their way back through the trench there was no one there alive. They had all been gassed or had frozen to death. Those who lay in water were profiled in ice. Everything was green: their faces - and their fingers - and their buttons. And the snow. ${ }^{19}$

Throughout increased interest in the First World War in the 1990s, fictional panoramas remained an unhappy place for Canada's naïve citizen-soldiers. For instance, Jack Hodgins' Broken Ground struggles with the legacy of the war through the tale of a returned soldier settlement in British Columbia's Comox district. The novel states that Flanders, in contrast to BC's verdant fields, produced, "a harvest of arms and blown-off feet and lost

\footnotetext{
${ }^{17}$ Alden Nowlan, “1914-1918” in Selected Poems, eds., Patrick Lane and Lorna Crozier (Toronto: Anansi, 1996), 159. Italicized in original.

${ }^{18}$ Robertson Davies, Fifth Business (Harmondsworth: Penguin, 1977), 80-81.

${ }^{19}$ Timothy Findley, The Wars (Harmondsworth: Penguin, 1986), 146. 
buttons and helmets and the surfacing rotted corpses of the dead." ${ }^{20}$ This recollection finds still further parallel in Jane Urquhart's The Stone Carvers. That novel's protagonist, Tilman, loses a leg at Vimy Ridge, a battle described thusly:

We barely understood where we were when it was all over. And let's not overlook the fact that thirty-five hundred guys died, and three times as many were injured. I didn't even hear about the grandness of the victory until the war was finished, and then I thought the fellow telling me had things all wrong. ${ }^{21}$

These characters illustrate more than just the unvarnished horror of war. They especially testify to an extreme lack of foresight. In every case, those who enlist are swept away by patriotism, revealed before long as misguided folly. As such, the prospect of being conscripted is irrelevant. The description of Tilman's enlistment in The Stone Carvers amply demonstrates this. A friend's father announces the declaration of war to Tilman, "as tears filled his eyes and the boys jumped to their feet with excitement." Although his fate has been conspicuously foreshadowed, he goes off to war shortly thereafter. ${ }^{22}$

The social memory of the conscription crisis proper is much more visible in Québécois literature. The Quiet Revolution of the 1960s saw the term Québécois replace Canadien, and antimilitarism came to be regarded by many as a defining characteristic of Québec society. Québécois literature reflects this monumental shift. Indeed, historian Mourad Djebabla has aptly-chronicled Québec writing on the Great War, which despite

${ }^{20}$ Jack Hodgins, Broken Ground (Toronto: McClelland \& Stewart, 1998), 104.

${ }^{21}$ Jane Urquhart, The Stone Carvers (Toronto: McClelland \& Stewart, 2001), 306.

${ }^{22}$ Ibid., 218. 
some veterans' accounts, did not become a subject of serious literary interest until the $1970 \mathrm{~s} .{ }^{23}$ Among the works which have been produced, Louis Caron's L'Emmitouflé remains both the best selling and the most in-depth in its exploration of the anti-militarist theme. ${ }^{24}$ Jean-François, son of Québécois migrants to Vermont and the novel's narrator, is attempting to dodge the Vietnam draft. His struggle evokes a winter of his youth, when his uncle, who concealed himself in the wilderness to avoid conscription during the Great War, went missing in the Green Mountains. The narrator becomes a draft dodger because of his uncle's actions, and the plot occasions juxtaposition between militarism and Québécois pacifism. When Jean-François' father politely asks the sheriff searching for his brother to stop bragging about his combat experiences during the Second World War, the sheriff asks what he did during the conflict. Jean-François' father replies: “J'ai travaillé pour la guerre moi aussi. J'étais dans une manufacture de lunettes à cette époque-là. Les lunettes qu'on faisait c'était pour les soldats. Vous voyez ça vous autres, un soldat sans ses lunettes." 25 This explanation is met with derisive laughter.

Indeed, the description of how the conscript is secured for service always overshadows other more mundane concerns. Descriptions of the event entail the snatch of an unsuspecting draftee under cover of darkness. In Two Solitudes, Tallard's hired hands share gossip about the capture of one of their neighbours:

\footnotetext{
${ }^{23}$ Mourad Djebabla, "Le récit de la Grande guerre dans la literature candiennefrançaise/québécoise des années 1919-1999 au Québec," Bulletin d'histoire politique, 11, 2 (hiver 2003), 114-28.

${ }^{24}$ For other fictional accounts of conscription in Québec, see Oscar Masse, $L a$ conscience de Pierre Laubier (Montréal: Beauchemin, 1943); Wilfrid Girard, Le Conscrit (Québec: Phare, 1972); Jacques Ferron, "Une confédération de villages," in Du Fond de mon arrière cuisine, ed., Jacques Ferron (Montréal: Éditions du Jour, 1973), 12326; Jean-François Delisle, La Guerre, Montréal (Montréal: Trait d'union, 1999).

${ }^{25}$ Louis Caron, L'Emmitouflé: roman (Montréal: Éditions du Seuil, 1991), 54. 
"'Yeh,' the hired men went on, 'Etienne's old woman screeching like a wildcat and the soldiers, the bastards, talking about a warrant. They took Napoléon right out in his drawers." ${ }^{26}$ When the men, always French, are captured, the authorities are invariably English. A similar description appears in L'Emmitouflé, when soldiers search a railway station for a deserter: "Ils etaient cinq ou six, ils 14| descendaient à la gare dans leur uniforme kaki et ils parlaient anglais entre eux." ${ }^{27}$ There are French-speaking soldiers and police, but only in subservient positions. ${ }^{28}$

Importantly, the Québec city riots are mentioned in every text, novel, or film set in Québec, as is the Ontario origin of the unit who violently put down the disturbances. L'Emmitouflés passage notes that the popular newspaper La Presse "disait ouvertement que des soldats avaient arrété des jeunes gens et qu'ils avaient déchiré leurs papiers d'exemption devant eux pour les enrôler de force." ${ }^{29}$ These accounts enumerate opposition to conscription, highlighting a reliable source's evidence that men were taken against their will. These circumstances make it clear that the enforcement of conscription was both an instrument and an abuse of the majority's power.

The popularity of these assumptions in both French and English Canada may be verified by their coverage in the recent Canadian Broadcasting Corporation project Canada: A People's History/Le Canada: Une histoire populaire. The episode concerning the conscription crisis, entitled "A Broken Promise," opens with the phrase: "Federal agents were combing the countryside...in

\footnotetext{
${ }^{26}$ MacLennan, Two Solitudes, 54.

${ }^{27}$ Caron, L'Emmitouflé, 95. See also 140-41.

${ }^{28}$ For example, see MacLennan, Two Solitudes, 158-61.

${ }^{29}$ Caron, L'Emmitouflé, 131-32.
} 
hundreds of Québec villages people take desperate measures to escape the sweep." 30 The portrayal of this operation is developed through ominous music, shots of a black car's tires rolling through a rural area, and a sudden knock upon the door of the Lachappele home. Fortunately for Monsieur Lachappele and his family, or so the film suggests, they have "borrowed" the child of one of their friends to avoid being registered by the unilingual English men seeking to conscript men without dependents. The episode also presents a wrenching segment on the Québec riots, centred on a moment of silence with photographs of the four people indiscriminately killed by "soldiers from Ontario and Western Canada." 31 This material clearly echoes the Québec nationalist position, precluding any attempt to explain the actions of the outsiders.

\section{Conclusion}

Most importantly, the vast majority of these constructions overlook the more pragmatic, and more difficult to stage in film or story, notions motivating opposition to conscription. This is mainly because no distinction is drawn between the Canada of 1917 and the Canada of the producer's present. Yet Canada was a very different place during the First World War, and any failure to acknowledge this assures that there will be no insight into the rural nature of the entire country, the tendency of French-Canadians to marry and have dependents at a young age, anglophone Protestant-led recruiting drives in a sectarian society, legislation

\footnotetext{
30 "A Broken Promise," Canada: A People's History Episode 12: Ordeal by Fire, 1:45 hours, Canadian Broadcasting Corporation, 2001, videocassette.

${ }^{31}$ Ibid. See also Le Canada: Une histoire populaire Ėpisode 12: L'épreuve du feu. 
proscribing the teaching of French in Ontario and Manitoba, and the fact that there was only one French language unit, the 22nd Battalion, in the military. In fact, the distinction that factored most heavily into enlistment decisions was not mother tongue or nationalist politics, but place of birth. Authors André Siegfried and Jacques Michel acknowledge this, as both hypothesized that the 16| CEF would have been larger and more representative if the numbers of French-born Canadians even approached the large number of British-born Canadians who enlisted. ${ }^{32}$ On the contrary, the longest-settled European-Canadians, the French, remained more concerned with the protection of their religion, their language, and their traditions than with a European war that did not directly threaten them.

Those attempting to explain this position, much less to reconcile it with nationalist social memory, have had little success in either fact or fiction. MacLennan's Athanase Tallard, who explored both sides of the conscription debate during a parliamentary speech, was simultaneously described as a traitor by the Montréal press and as an anti-war agitator in Toronto. Athanase was likewise lonely in his recognition of the Québec contribution overseas, stating:

The Canadians had actually been the ones to send the German Army on its way back to the Rhine. The Royal Twenty-Second was right up in the front, where it belonged. Why couldn't a fool like Marius see that the Twenty-Second was as representative of Quebec as all

\footnotetext{
${ }^{32}$ André Siegfried, Le Canada: Puissance Internationale (Paris: Librairie Armand Colin, 1937), 193-96; Jacques Michel, La Participation des Canadiens Français à la grande guerre (Montréal: Éditions de L'A.C.-F, 1938), 19. See also Adolphe Brassard, Mémoires d'un soldat inconnu: roman (Montréal: n.p. 1939), 108-10.

Past Imperfect 12 [2006] | (C) | ISSN $1192-1315$
} 
the long-haired, big-mouthed, thin-shouldered friends he had made in college ? $^{33}$

The Québec nationalist perception downplays this as well, since opposition to conscription is only part and parcel of the larger opposition to all wars. ${ }^{34}$ Whether Jean-François' father supported the war effort, particularly because his work at the glasses' factory came about because of it, is left open to more subtle interpretation.

of course, virtually all of these accounts are concerned with the literal and figurative centre of Canada, Ontario and Québec. While input from the so-called "periphery" has been much more common since the 1970s, this wider separation is also an important part of the conscription crisis. For example, the description of the 1917 election in the federal production Canada and the Great War states: "The issue of conscription had divided the nation. The Liberals won 62 of the 65 seats in Quebec, only 2 of 57 seats in Western Canada; and 8 of 82 in Ontario." ${ }^{35}$ In the one region not mentioned, the Maritimes, ten of thirty one seats - reduced from seventeen by military votes - went Liberal. The narrative ignores this both because the Maritimes are considered unimportant and to avoid an unnecessary anomaly in a thesis neatly presented for public school consumption. In this way, Canadian nationalism

\footnotetext{
${ }^{33}$ MacLennan, Two Solitudes, 62-3, 156.

${ }^{34}$ For more on this debate, see L.G. Desjardins, L'Angleterre, le Canada, et la Grande Guerre (Québec: n. , 1917); Elizabeth H. Armstrong, The Crisis of Quebec, 1914-18 (New York: Columbia University Press, 1937); Chubby Power, Party Politician: The Memoirs of Chubby Power (Toronto: Macmillan of Canada, 1966), 55; Gérard Filteau, Le Québec, le Canada, et la Guerre 1914-1918 (Montréal: Éditions de L'Aurore, 1977); Roch Legault and Jean Lamarre, eds., La Première Guerre Mondiale et le Canada: contributions sociomilitaires québécoises (Montréal, 1999); Claude E. Léger, Le bataillon acadien de la Première Guerre mondiale (Moncton: Self-published, 2001); Flavien Héreault, "La perception de la Première Guerre mondiale au Québec de 1914 à aujourd'hui: un projet," Bulletin d'histoire politique, 11, 2 (hiver 2003), 129-33.

${ }^{35}$ Canada, Canada and the Great War 1914-1918: A Nation Born, An Educational Resource (Ottawa: Veterans Affairs Canada, 1998), 51.
} 
dodges any other discontent that may have been present, either in the past or at the time of writing, to concentrate on Québec. Québec nationalism supports this position, largely because the ideology is not concerned with finding allies in Canada.

Deviations from this centre of gravity are uncommon, although the Canadiana Scrapbook asks "Which provinces voted 18| against the government?" The answer key correctly reveals Québec, Nova Scotia, and Prince Edward Island. Furthermore, L'Emmitouflé-like stories of deserters concealing themselves in the woods near Arden and the widespread agricultural exemptions granted in Tilman's hometown of Shoneval, demonstrate that there was even resistance to conscription within Ontario. ${ }^{36}$ In essence, however, all works devote minimal attention to divisions between farmers and urbanites, soldiers and civilians, and Liberals and Conservatives, making it abundantly clear that the truly important division was that between French (Québec) and English (Ontario) Canadians.

Division of this kind is nothing new, but one of the worst crises in Canada's collective past certainly deserves better. At present, the conscription crisis is either ignored for the sake of Canadian nationalist unity or mythologized for the sake of Québec sovereignty demands. There needs to be more room for different perceptions of the conscription crisis. An injection of badly-needed context, alongside attempts to empathize with contemporary Canadian decision-makers, is the first step in this process. Ethnicity and mother tongue played vital roles in the many responses to the conscription crisis, but there was much more involved. Introducing

\footnotetext{
${ }^{36}$ Santor, Teacher's Guide, 71; Urquhart, The Stone Carvers, 243; Daphne Read, ed., The Great War and Canadian Society: An Oral History (Toronto: New Hogtown Press, 1978), 109-10. 
the experiences of occupational groups and of the regions could only be beneficial. Indeed, this subject is a prime example of the benefit of regional history, since more regionally-based research fosters wider understanding. Canadians' social memory of the conscription crisis needs to better reflect both the connections and the many differences that comprised such a substantial component of those trying times. 